\title{
Induction by TNF- $\alpha$ of IL-6 and IL-8 in Cystic Fibrosis Bronchial IB3-1 Epithelial Cells Encapsulated in Alginate Microbeads
}

\author{
Monica Borgatti, ${ }^{1}$ Stefania Mazzitelli, ${ }^{2}$ Giulia Breveglieri, ${ }^{1}$ Roberto Gambari, ${ }^{1}$ \\ and Claudio Nastruzzi ${ }^{2}$ \\ ${ }^{1}$ BioPharmaNet, Department of Biochemistry and Molecular Biology, Ferrara University, 44121 Ferrara, Italy \\ ${ }^{2}$ CAPS-IT, Department of Chemistry and Technology of Drugs, University of Perugia, 06123 Perugia, Italy
}

Correspondence should be addressed to Roberto Gambari, gam@unife.it and Claudio Nastruzzi, nas@unipg.it

Received 23 March 2010; Revised 21 June 2010; Accepted 28 June 2010

Academic Editor: Douglas Cyr

Copyright ( $) 2010$ Monica Borgatti et al. This is an open access article distributed under the Creative Commons Attribution License, which permits unrestricted use, distribution, and reproduction in any medium, provided the original work is properly cited.

\begin{abstract}
We have developed a microencapsulation procedure for the entrapment and manipulation of IB3-1 cystic fibrosis cells. The applied method is based on generation of monodisperse droplets by a vibrational nozzle. Different experimental parameters were analyzed, including frequency and amplitude of vibration, polymer pumping rate and distance between the nozzle and the gelling bath. We have found that the microencapsulation procedure does not alter the viability of the encapsulated IB3-1 cells. The encapsulated IB3-1 cells were characterized in term of secretomic profile, analyzing the culture medium by Bio-Plex strategy. The experiments demonstrated that most of the analyzed proteins, were secreted both by the free and encapsulated cells, even if in a different extent. In order to determine the biotechnological applications of this procedure, we determined whether encapsulated IB3-1 cells could be induced to pro-inflammatory responses, after treatment with TNF- $\alpha$. In this experimental set-up, encapsulated and free IB3-1 cells were treated with TNF- $\alpha$, thereafter the culture media from both cell populations were collected. As expected, TNF- $\alpha$ induced a sharp increase in the secretion of interleukins, chemokines and growth factors. Of great interest was the evidence that induction of interleukin- 6 and interleukin-8 occurs also by encapsulated IB3-1 cells.
\end{abstract}

\section{Introduction}

Cystic fibrosis (CF) is an autosomal recessive disorder caused by mutations of the CF transmembrane conductance regulator (CFTR) gene, which encodes a transmembrane protein present on a variety of cell types and organelles [1]. The most common mutation of the CFTR gene is a 3-base-pair deletion resulting in the deletion of phenylalanine at position 508, known as the F508del CFTR mutation [1]. While CF is classically characterized by the presence of pancreatic insufficiency and recurrent lung infections in infants, a wide clinical spectrum has been identified in adults $[2,3]$. Chronic bacterial infection of the airways, thickened airway mucous, and bronchiectasis characterizes the CF lung [4]. The excess of mucus is largely caused by the influx of neutrophils, attracted to the site by the increased expression of chemokines such as interleukin-6 (IL-6) [5] and interleukin-8 (IL-8) [5, 6], by bacterial products and inflammatory cytokines.
For instance, IL-8, produced by macrophages, epithelial cells, and fibroblasts, is a potent chemokine and activator for human neutrophils and it is considered to be an important proinflammatory cytokine in the pathogenesis of CF $[2,6-8]$. IL-8 is induced transcriptionally by a wide variety of stimuli including tumor necrosis factor-alpha (TNF- $\alpha$ ), hyperosmotic shock, and bacterial products such as lipopolysaccharides [9].

In order to possibly study in detail the mechanism(s) of activation of IL-8 in CF, there has been recently proposed the IB3-1 cell system [10]. IB3-1 is a bronchial epithelial cell line, derived from a CF patient with a CFTR genotype of F508del/W1282X, therefore carrying the associated cystic fibrosis mutation [10-12]. This cell line can be induced to high expression of proinflammatory proteins, following infection with Pseudomonas aeruginosa or by treatment with TNF- $\alpha$. In both cases, 24 -hour treatment with TNF- $\alpha$ is usually sufficient to induce in IB3-1 cells a deep alteration of 
mRNA expression and protein secretion profile with a typical increase of IL- 6 and IL- 8 mRNA and IL-6/IL-8 release [11].

Taking into consideration what stated above, it would be of great interest to develop a specific system to possibly study the mechanism of bacterial activation of IB3-1 cells as well as the effect of the secreted chemokines on target cell populations, in coculture experiments. For instance, IB3-1 cells could be cocultured with Pseudomonas aeruginosa or polymorphonuclear cells (PMN), the major phagocytic cells of blood and also with other inflammatory cells such as basophils, eosinophils, and T-cells $[13,14]$.

The coculture experiments could be performed in the presence/absence of a semipermeable membrane embedding the IB3-1 cells, representing a physical barrier to cell/cell interactions but allowing the cross-talking among the different cells mediated by soluble factors.

In this respect, polysaccharidic-based microbeads represent one of the most intensively studied system to immunoisolate cells or cell clusters, because of the spherical shape and the small size that offer an optimal surface to volume ratio and an optimal diffusion capacity $[15,16]$.

The technology of cell microencapsulation is based on the immobilization of living cells within a polymer matrix, often alginate, that constitutes a semipermeable membrane $[15,17]$. The encapsulated cells are protected against immune cell- and antibody-mediated actions and have the potential to secrete active substances, generally with a molecular weight $\leq 90 \mathrm{kDa}[15,17]$.

These "living" delivery systems have been proposed for controlled and continuous expression of a number of compounds including hormones, growth factors, and biological response modifiers.

The aim of the research work, here reported, is to determine whether IB3-1 cells can be conveniently encapsulated in polymeric microbeads maintaining long-term in vitro viability as well as their secretomic profile when cultured in standard conditions or after stimulation with TNF- $\alpha$.

Summarizing, the current paper describes the following: (a) the encapsulation of IB3-1 cells in alginate microbeads following a microencapsulation procedure developed in our laboratory that is based on the generation of monodisperse droplets by an air-driven droplet generator for cell encapsulation; (b) the characterization of alginate microbeads produced, with different experimental parameters, including atomizing air, polymer pumping rate, and distance between the nozzle and the gelling bath; (c) the determination of viability of the encapsulated IB3-1 cells, and finally (d) the characterization of the encapsulated IB3-1 cells, in terms of secretomic profile, analyzing the culture medium by BioPlex strategy [18-20]. The analyzed factors include members of the interleukin family, chemokines, growth factors and soluble forms of adhesion molecules.

\section{Materials and Methods}

2.1. Cell Cultures. IB3-1 cells were obtained from LGC Promochem (Teddington, Middlesex, UK). Cells were grown in LHC-8 basal medium (Biofluids, Rockville, MD, USA), supplemented with 5\% FBS in the absence of gentamycin.
All culture flasks and plates were coated with a solution containing $35 \mathrm{mg} / \mathrm{mL}$ bovine collagen (Becton-Dickinson Italia, Milan, Italy), $1 \mathrm{mg} / \mathrm{mL}$ bovine serum albumin (Sigma, St. Louis, MO, USA), and $1 \mathrm{mg} / \mathrm{mL}$ human fibronectin (Becton-Dickinson) [10].

2.2. Encapsulation of IB3-1 Cells. Monodisperse alginate beads containing IB3-1 cells were prepared using an airdriven droplet generator for cell encapsulation. Before encapsulation, confluent monolayers of IB3-1 were scraped off by $0.05 \%$ trypsin/EDTA (Gibco, Grandisland, NY, USA) ( 2 min), washed with PBS, counted by hemocytometric analysis, and assayed for viability by double staining with propidium iodide (PI) and Calcein-AM (Sigma), following the manufacturer's indications. Briefly, IB3-1 cells were suspended in a $1.5 \%(\mathrm{w} / \mathrm{v})$ aqueous solution of highly purified sodium alginate (Inotech, Dottikon, Switzerland) at a concentration of $8-12 \times 10^{6}$ cells $/ \mathrm{ml}$. The resulting cell suspension was continuously aspirated by a syringe pump and extruded through the air-driven droplet generator, under sterile conditions. The generated microdroplets were harderned by an ionotropic gelling process into a 1.2\% (w/v) barium chloride solution that resulted in the production of barium alginate microbeads. After 3-minute incubation into the gelling bath, the microbeads were washed twice with saline and placed in LHC-8 basal medium (Biofluids), supplemented with $5 \% \mathrm{FBS}$ at $37^{\circ} \mathrm{C}$ in an humidified atmosphere of $5 \% \mathrm{CO}_{2}$.

\subsection{Dimensional and Morphological Characterization of} Alginate Microbeads. The morphology of barium alginate microbeads was evaluated by optical microscopy and stereomicroscopy (Nikon microscopes, Tokyo, Japan). Microbead size was determined by photomicrograph analyses (Eclipsenet version 1.16.5; Laboratory AU5c Imaging s.r.o. for Nikon B.V.). Samples of 200-400 beads were considered.

2.4. Viability Determination of Encapsulated IB3-1 Cells. After encapsulation and after different lengths of time, the viability of IB3-1 cells was analyzed by double staining with propidium iodide (PI) and Calcein-AM, following manufacturer's instructions. For the propidium iodide (PI) and Calcein-AM analysis, cells were visualized under a fluorescence microscope (Nikon, Optiphot-2, Nikon Corporation, Japan). Viable cells were stained in green while the dead ones were stained in red.

2.5. Experimental Design and Statistical Analysis. To study the effect and the influence of different experimental parameters on the size and size distribution of alginate microbeads, a randomized central compositive face (CCF)centered design (CCF) consisting of 17 runs was used. The experimental design and the evaluation of the experiments were performed by the PC software MODDE 8.0 (Umetrics $\mathrm{AB}$, Sweden), followed by multiple linear regression (MLR) algorithms. The following experimental parameters ("factors") were considered: the atomizing air flow ("air"), the alginate pumping rate ("pump"), and the distance between 
the nozzle of air-driven droplet generator and the surface of the gelling bath ("height").

2.6. Treatment of IB3-1 with TNF- $\alpha$. Treatment of monolayers: IB3-1 cells were seeded at the initial concentration of 30,000 cells $/ \mathrm{cm}^{2}$ and the cell number/ml determined after 3 days of culture. Cell number/ml was determined after trypsin treatment by using a model ZBI Coulter Counter (Coulter Electronics, Hialeah, FL, USA). Treatment of monolayers with $80 \mathrm{ng} / \mathrm{mL}$ TNF- $\alpha$ (PeProTech EC, London, UK) was performed on $70 \%$ confluent cells for 24 hours. Treatment of encapsulated cells: equal quantity $\left(20 \times 10^{6}\right.$ cells $)$ of free and encapsulated cells (derived from the same flask, previously cultured for 3 days and successively detached by trypsin) was treated with $80 \mathrm{ng} / \mathrm{mL}$ TNF- $\alpha$ for 24 hours.

2.7. Cytokine Profiles. Cytokines in tissue culture supernatants released from the cells under analysis were measured by Bio-Plex cytokine assay (Bio-Rad Laboratories, Hercules, CA) [21] as described by the manufacturer. The Bio-Plex cytokine assay is designed for the multiplexed quantitative measurement of multiple cytokines in a single well using as little as $50 \mu \mathrm{L}$ of sample. In our experiments, the premixed multiplex beads of the Bio-Plex human cytokine 7-plex which included seven cytokines IL-1r $\alpha$, IL-6, IL-8, G-CSF, MCP-1 (MCAF), RANTES, and VEGF were used. $50 \mu \mathrm{L}$ of cytokine standards or samples (supernatants recovered from treated cells) were incubated with $50 \mu \mathrm{L}$ of anticytokine conjugated beads in 96-well filter plates for $30 \mathrm{~min}$ at room temperature with shaking. Plates were then washed by vacuum filtration three times with $100 \mu \mathrm{L}$ of Bio-Plex wash buffer, $25 \mu \mathrm{L}$ of diluted detection antibody were added, and plates were incubated for $30 \mathrm{~min}$ at room temperature with shaking. After three filter washes, $50 \mu \mathrm{L}$ of streptavidinphycoerythrin were added, and the plates were incubated for $10 \mathrm{~min}$ at room temperature with shaking. Finally, plates were washed by vacuum filtration three times, beads were suspended in Bio-Plex assay buffer, and samples were analyzed on a Bio-Rad 96-well plate reader using the Bio-Plex Suspension Array System and Bio-Plex Manager software (Bio-Rad Laboratories).

2.8. Quantification of IL-8 and IL-6 Transcripts. Total RNA was isolated (High Pure RNA isolation kit, Roche Applied Science, Monza, Italy) and retro-transcribed (Promega Corporation, Madison, USA), and the resulting cDNA was quantified by relative quantitative real-time PCR. The sequences of the oligonucleotides used for amplification of IL-8 mRNA were as follows: $5^{\prime}$-GTG CAG TTT TGC CAA GGA GT-3' (forward) and $5^{\prime}$-TTA TGA ATT CTC AGC CCT CTT CAA AAA CTT CTC-3' (reverse); for IL-6 mRNA: $5^{\prime}$-AGG AGA CTT GCC TGG TGA AA-3' (forward) and $5^{\prime}$-CAG GGG TGG TTA TTG CAT CT- $3^{\prime}$ (reverse); for GAPDH mRNA: $5^{\prime}$-AAG GTC GGA GTC AAC GGA TTT-3' (forward) and 5' ACT GTG GTC ATG AGT CCT TCC A-3' (reverse). For RealTime (RT) PCR, $0.5 \mu \mathrm{L}$ of cDNA were used for each Sybr Green RT-PCR reaction to quantify the relative tissue expression of IL- 8 and IL- 6 transcripts. Each $25 \mu$ L of total reaction volume contained $0.5 \mu \mathrm{L}$ of cDNA, $10 \mathrm{pmol}$ of primers, $1 \times$ iQ SYBR Green Supermix (Bio-Rad Laboratories). Realtime PCR reactions were performed for a total of 40 cycles (denaturation, $95^{\circ} \mathrm{C}$ for $10 \mathrm{~s}$; annealing, $68^{\circ} \mathrm{C}$ for $30 \mathrm{~s}$ for IL$8,65^{\circ} \mathrm{C}$ for $30 \mathrm{~s}$ for IL-6; elongation, $72^{\circ} \mathrm{C}$ for $60 \mathrm{~s}$ ) using an iCycler IQ (Bio-Rad Laboratories). The relative proportions of each template amplified were determined based on the threshold cycle $\left(\mathrm{C}_{t}\right)$ value for each PCR reaction. The $\Delta \Delta \mathrm{Ct}$ method was used to compare gene expression data. Each sample was quantified in duplicate from at least two independent experiments. Mean \pm S.D. values were determined for each fold difference. Amplification of human GAPDH cDNA served as internal standard (housekeeping gene). Duplicate negative controls (no template cDNA) were also run with every experimental plate to assess specificity and indicate potential contamination.

2.9. Data Analysis and Statistics. Statistical analysis was performed by one-way analysis of variance followed by the Student's $t$-test. A $P$ value $<.05$ was considered statistically significant.

\section{Results}

3.1. Release of Proinflammatory Proteins by IB3-1 Cells Exposed to TNF- $\alpha$ : a Bio-Plex Analysis. IB3-1 cystic fibrosis cell monolayers (see Figure 1(a)) were treated, after 3 days of cell culture, for 24 hours in the presence of $80 \mathrm{ng} / \mathrm{mL}$ of TNF- $\alpha$; thereafter, the conditioned media, from treated and control cell populations, were analyzed for presence of proinflammatory cytokines by Bio-Plex mediated analysis. Before each induction experiment, IB3-1 cell monolayers were assayed by "live/dead cells" test; in all cases the determined viability was $\geq 90 \%$, as indicated by the fluorescence photomicrographs reported in the insets of Figure 1(a).

The Bio-Plex 200 multiplex suspension array represents, in fact, an assay system, employing Luminex xMAPtechnology, for the simultaneous detection and quantitation of multiple bioanalytes (proteins, peptides, DNA and RNA) in a single microplate, requiring only very small sample volumes.

A number of proteins were considered in the analysis of IB3-1 medium, namely, IL-1r $\alpha$, G-CSF, MCP-1, IL-6, IL-8, RANTES, and VEGF. The obtained data, reported in Figures $1(\mathrm{~b})$ and 1(c), indicate that, apart from RANTES and VEGF (which values are not statistically different in control versus treated cells), all other proteins are differentially expressed and released in untreated IB3-1 cells and after TNF- $\alpha$ treatment. In particular, IL- 6 and IL- 8 were present at high concentrations, in the medium of TNF- $\alpha$ treated cells, reaching values of 5.71 and $5.84 \mathrm{ng} / \mathrm{mL}$, respectively.

3.2. Encapsulation of IB3-1 Cells in Alginate Microbeads. IB31 cells were embedded into alginate microbeads by an airdriven droplet generator for cell encapsulation (see scheme in Figure 2). The encapsulation procedure was relatively simple and consisted of a limited number of steps. In order to achieve complete biocompatibility, essential for 


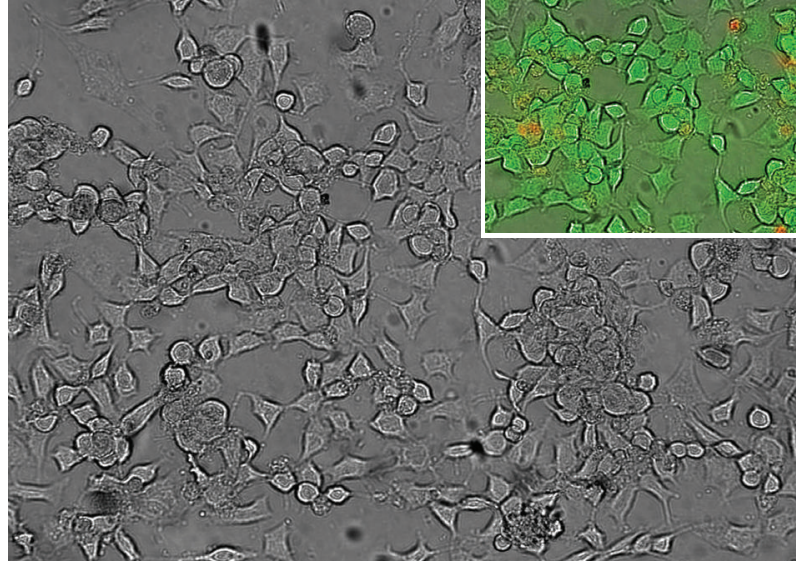

(a)

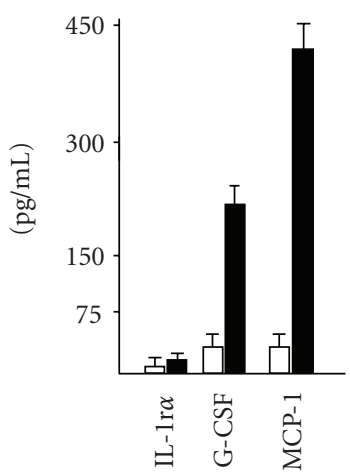

(b)

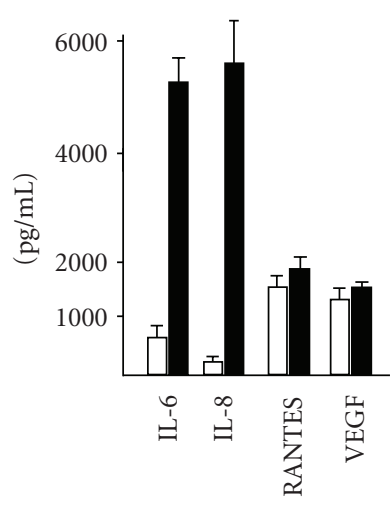

(c)
Figure 1: Morphology (a) and viability (insert) of IB3-1 cell monolayers, as determined by bright field and fluorescence photomicrographs. Fluorescence photomicrographs were taken after double staining with Calcein-AM and propidium bromide. Analysis of the release of proinflammatory cytokines by IB3-1 cells, as determinated by Bio-Plex analysis $(b, c)$. The indicated proteins were analyzed in the IB3-1 cell culture medium, namely, IL-1r $\alpha$ (Interleukin1 receptor alpha), G-CSF (Granulocyte-colony stimulating factor), MCP-1 (Monocyte chemotactic protein-1), IL-6 (Interleukin 6), IL-8 (Interleukin 8), RANTES (Regulated upon activation, normal $\mathrm{T}$ cell expressed and secreted), and VEGF (Vascular endothelial growth factor). Data are referred to control untreated cells (open bars) and to cells treated for 24 hours with TNF- $\alpha(80 \mathrm{ng} / \mathrm{mL})$ (closed bars). Data represent the average $\pm \mathrm{SD}(N=3)$.

mammalian cells, the entire procedure was conducted at room temperature, under physiologic $\mathrm{pH}$ and tonicity using a pyrogen-free alginate $[16,17]$. The hardening of the generated alginate microdroplets was accomplished by an ionic gelation procedure, by barium chloride. The resulting barium alginate microbeads were elastic and transparent, thus facilitating the microscopic observation of cell morphology and viability, during the in vitro studies, as evident by the brightfield and darkfield stereophotomicrographs shown in Figure 3.

For the screening and optimization of the experimental parameters, a "design of the experiments" (DoE) was performed, after design by MODDE software. The DoE reduces the number of experiments and provides statistical information about the effects of different variables and their possible interactions.

A central composite design (one of the most used designs in pharmaceuticals and biological studies) was applied to the optimization of alginate microbeads. This experimental design required 17 experiments $(2 k+2 k+3$, where $k$ is the number of variables) including three center points in order to have an estimation of the experimental error. The high and low values of each variable were defined based on preliminary experiments.

The factors/responses and the general results of DoE analysis are reported in Table 1 and Figures 4 and 5, respectively. In particular, in Figure 4 are shown the contour plots, while the response surface plots of the investigated factors are given in Figure 5; the influence of factors on "size" is given in (a)-(c) and "SD" in (d)-(f).

The main observation was that a change in "air" value from a low to a high level (12 to 20 bar) results in a sharp decrease of the microbead "size" while the "SD" response presents a biphasic trend showing a minimum at the central value for both "air" and "pump". The "height" and "pump" parameters exert an influence at their high and low levels causing the increase of both the responses. After investigation of the factor influence, the validity and the significance of the model was estimated by analysis of variance (ANOVA). All the data obtained fit well the model determining a good reproducibility of the studied model. We get a large regression coefficient $R^{2}$ that is a necessary condition for a validity model with a significant power of prediction of the model $\mathrm{Q}^{2}$ (data not shown).

3.3. Viability of Encapsulated IB3-1 Cells. A crucial issue that should be always investigated in the case of embedding/seeding protocols for cell scaffolding concerns the effect of the encapsulation procedure on viability of cells. For this purpose, the viability of encapsulated cells in alginate beads was determined by the live/dead test. Beads were incubated with Calcein-AM (a marker of living cells; fluorescent signal was monitored using $485 \mathrm{~nm}$ excitation wavelength and $530 \mathrm{~nm}$ emission wavelength) and with PI (a marker of cell death; excitation, $535 \mathrm{~nm}$; emission, >610 nm). The observation of the fluorescent images recorded immediately after the encapsulation procedure at the typical excitation wavelengths (Figure 6) indicated that the cells were highly viable (>95\%) after different lengths of culture time (up to 7 days).

3.4. Increase of Accumulation of IL-8 and IL-6 mRNAs Is Clearly Detectable in Encapsulated IB3-1 Cells Treated with TNF- $\alpha$. Free and encapsulated IB3-1 cystic fibrosis cells were treated for 24 hours in the presence of $80 \mathrm{ng} / \mathrm{mL}$ of TNF- $\alpha$. After this treatment, microcapsules were separated from the culture medium, washed, fused and entrapped cells isolated, washed, and finally lysed for RNA isolation. RT-PCR was performed using primers amplifying IL-8, IL-6, and GAPDH RNA sequences. The results obtained are reported in Figure $7(\mathrm{a})$, which clearly indicates that encapsulation has only minor effects on IL-8 mRNA accumulation. Consistently, in 


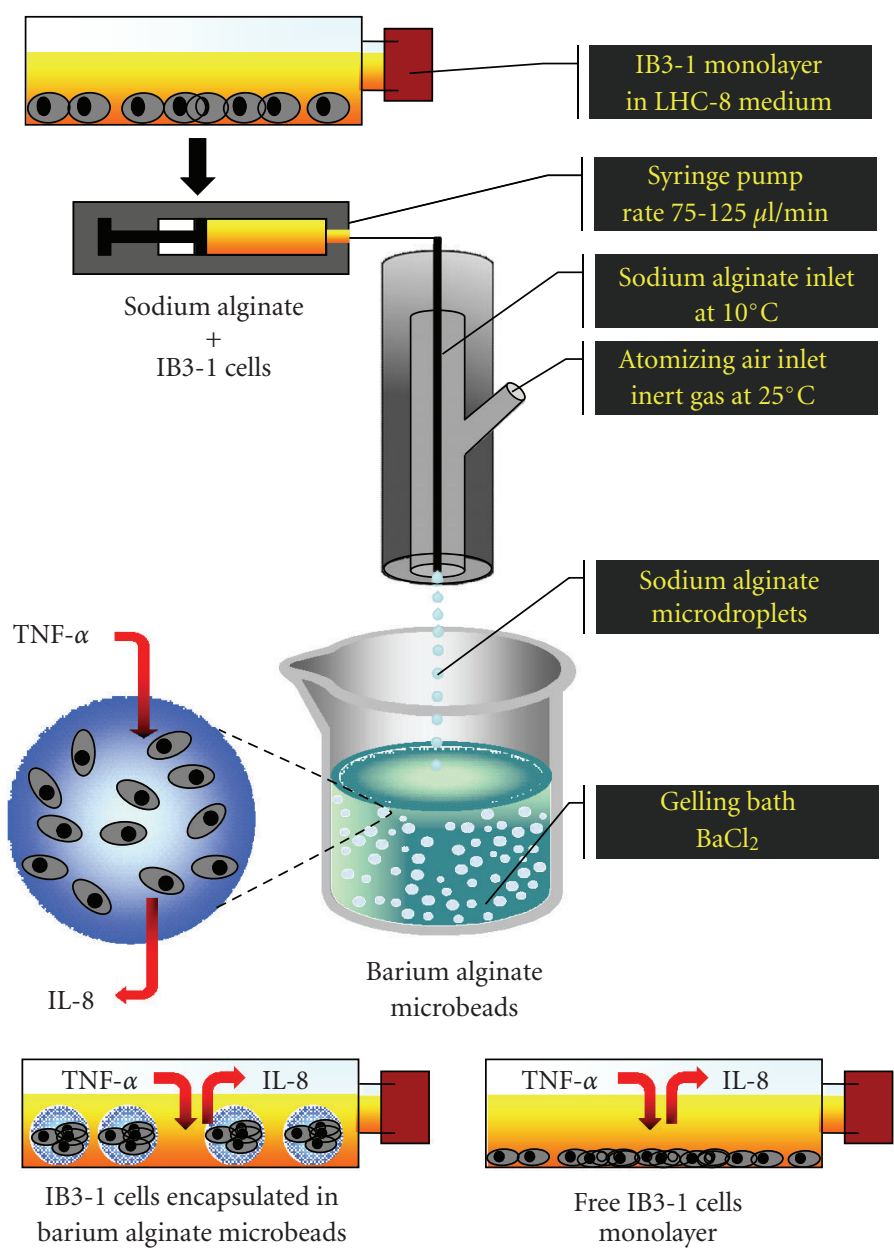

FIGURE 2: General scheme of the encapsulation procedure for IB3-1 cells by monojet air-driven device. The lower part of the figure summarizes the procedure for the in vitro experiments with free (right) and encapsulated IB3-1cells (left) treated with TNF- $\alpha$.

TNF- $\alpha$-treated cells (closed bars) the levels of IL- 6 and IL8 mRNA sequences are higher than those usually found in TNF- $\alpha$ untreated IB3-1 cells (open bars). Moreover, TNF- $\alpha$ induction of IL-6 (Figure 7(a), left side of the panel) and IL-8 (Figure 7(a), right side of the panel) gene expression is clearly evident, both in free (control) and encapsulated (CAPS) IB31 cells, strongly indicating that (a) TNF- $\alpha$ transfer within the alginate microbeads takes place with high efficiency and (b) its expected effects on gene expression is detectable, mimicking the well-known effect of TNF- $\alpha$ on free IB3-1 cells. In order to determine whether the increases of IL-6 and IL-8 mRNA direct synthesis of the respective proteins and their secretion outside the alginate microbeads, Bio-Plex analysis on the medium was performed.

3.5. Increased Release of IL-6 and IL-8 outside the Microcapsules Entrapping IB3-1 Cells Treated with TNF- $\alpha$. Free and encapsulated IB3-1 cystic fibrosis cells were treated for 24 hours in the presence of $80 \mathrm{ng} / \mathrm{mL}$ of TNF- $\alpha$. After this treatment, microcapsules were separated from the culture medium, which was analyzed for content of IL-6 and IL8. Figure 7(b) shows that minor differences in the amounts of secreted IL- 6 and IL-8 protein levels are present when mediums isolated from cultures of free (control) and encapsulated (CAPS) IB3-1 cells are compared. On the contrary, when release by TNF- $\alpha$-treated cells is compared to that of control IB3-1 cells (compare black to white histograms of Figure 7(b)), the levels of IL-6 and IL-8 increase significantly both in free (control) and in encapsulated (CAPS) IB3-1 cells. The TNF- $\alpha$-mediated fold induction of IL- 8 release was found similar in free and encapsulated IB3-1 cells (Figure 7(b), right side of the panel), while in the case of IL-6, the fold increase was more evident in free IB3-1 cells (Figure 7(b), left side of the panel). This observation was reproducibly obtained in several experiments.

\section{Discussion}

The first aim of the present paper was to verify if IB31 cystic fibrosis cells could be encapsulated in alginate microbeads and to test if the immobilized cells could be induced to express proinflammatory genes, after treatment with TNF- $\alpha$ (see the scheme of the experiment shown in Figure 2). In this respect, we demonstrated that 


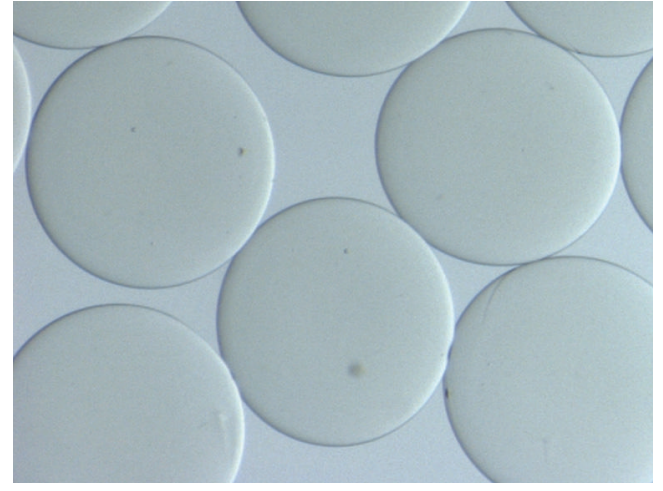

(a)

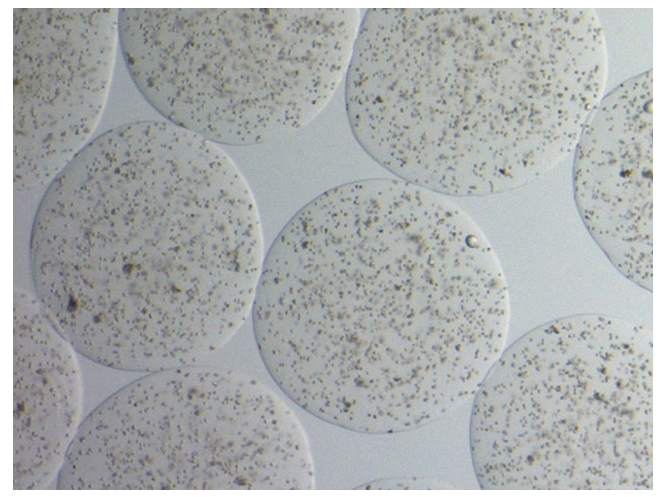

(b)

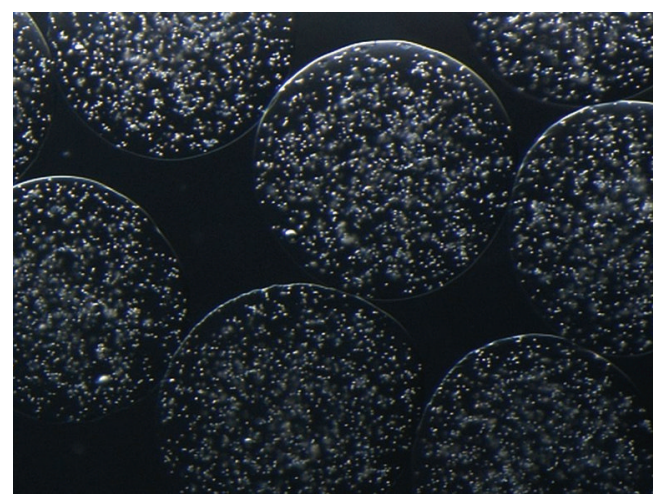

(c)

Figure 3: Bright field (a,b) and dark field (c) stereophotomicrographs of empty (a) and IB3-1 containing (b,c) alginate microbeads. Microbeads were produced by the monojet air-driven device. Alginate microbeads were prepared using the experimental parameters reported in Table 1 (batch \#15a, b, c).

IB3-1 cells can be efficiently encapsulated in microbeads that posses a number of specific requisites, such as spherical shape, very narrow size distribution, good mechanical stability, and biocompatibility, assuring cell viability and functions. These findings are in agreement with several observations indicating that this strategy is a useful tool to entrap functionally active cells, as published by several research groups [22-24]. For instance, human mesenchymal progenitor cells were immobilized in alginate microbeads by Endres et al. [23] and by Penolazzi et al. [24], demonstrating that after encapsulation, they maintain the ability to undergo chondrogenic differentiation.

The second aim of our experimental strategy was to verify whether TNF- $\alpha$ efficiently induces gene expression alterations in the encapsulated IB3-1 cells. The results obtained by RT-PCR analysis of RNA firmly demonstrate that (a) encapsulation induces only a limited increase of the basal IL-6 and IL- 8 mRNA content, whereas (b) TNF$\alpha$ stimulates a sharp increase of content of IL- 6 and IL-8 mRNAs in both free and encapsulated IB3-1 cells. This latter result suggests that TNF- $\alpha$ efficiently diffuses through the alginate microbeads matrix. Therefore, alginate microbeads could be suitably employed in experiments, in which the target cells are grown in a physically separated, immunoisolated environment, being however accessible to externally added soluble proteins possibly causing alterations of gene expression.

However, in order to propose the described system as an experimental model to study cystic fibrosis, further experiments are required to control several unmet issues, including the fact that the encapsulated cells are nonadherent, are not polarized and are unable to bind to bacteria (such as Pseudomonas aeruginosa) and immune cells inducing responses very different from those of soluble mediators (i.e., TNF- $\alpha$ ). These are several parameters playing important roles in modification of gene expression in cystic fibrosis cells [25-27]. In this respect, we like to underline that the alginatebased encapsulation strategy can be further improved. For instance, in our laboratories, experiments in progress are aimed to the production of composites multifunctional microbeads simultaneously containing (a) living cells and (b) an extracellular matrix component, namely, a particulate ECM, that is able to modulate cell adhesion, migration, and polarization. In addition, coencapsulation of epithelial cells and effector cells is technically feasible and might be explored.

Finally, the third aim of our experimental strategy was to verify whether TNF- $\alpha$ treatment leads to increased production and release of IL- 6 and IL-8, confirming the permeability of the alginate microbeads membrane to these proteins. The results obtained firmly demonstrate that IL-6 and IL- 8 release outside the microbeads increases in IB3-1 encapsulated cell cultures strongly suggesting that the alginate microbeads membrane is permeable to these proteins. However, while the TNF- $\alpha$-mediated fold induction of IL- 8 release was found similar in free and encapsulated IB3-1 cells, we reproducibly noted that in the case of IL- 6 the fold increase was more evident in free cells than that in encapsulated IB3-1 cells. This might be due to a differential intracellular synthesis of IL- 6 and IL- 8 mRNAs or to a differential permeability of the capsule membranes to IL- 6 and IL- 8 , or both. While additional experiments are required to explain this phenomenon, the possibility that the chemical composition of the microcapsule influences drug release characteristics has been recently proposed by Jaya et al. and might be used to develop microbeads allowing selective releases [28]. 

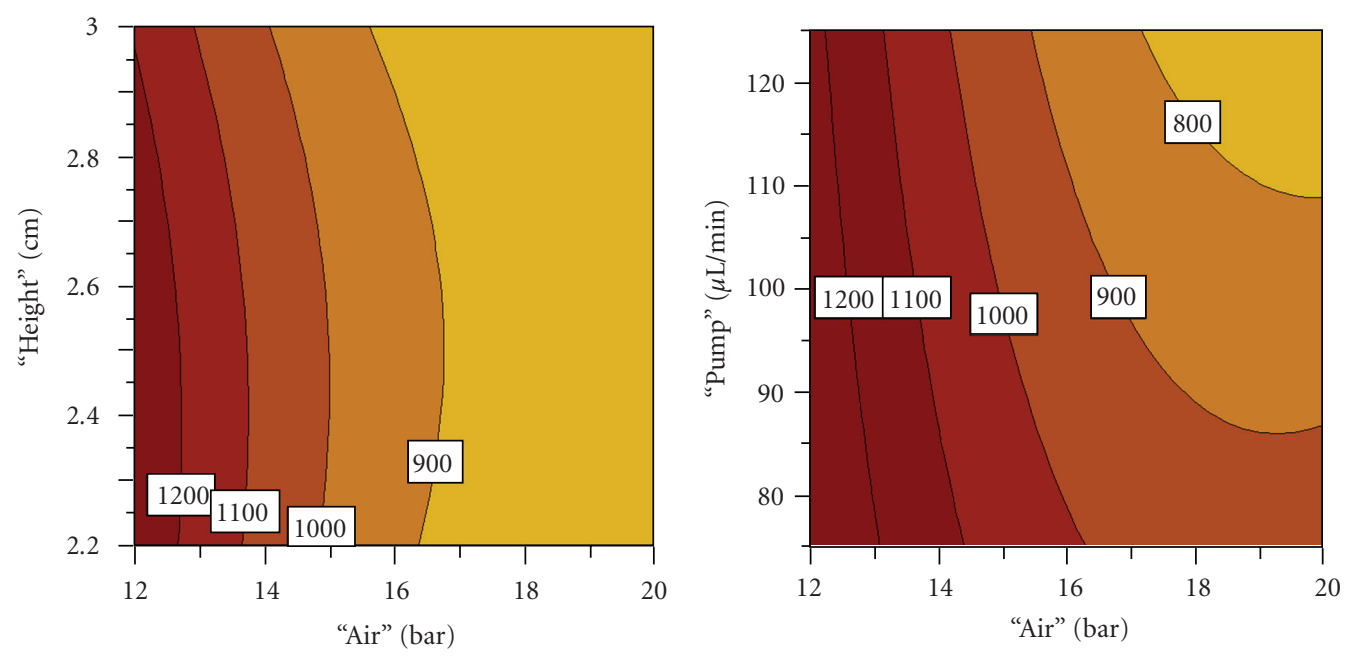

(a)

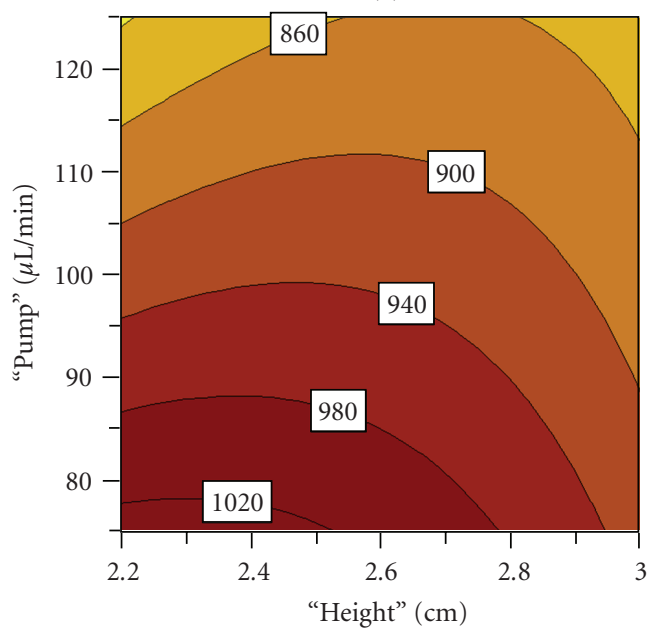

(b)

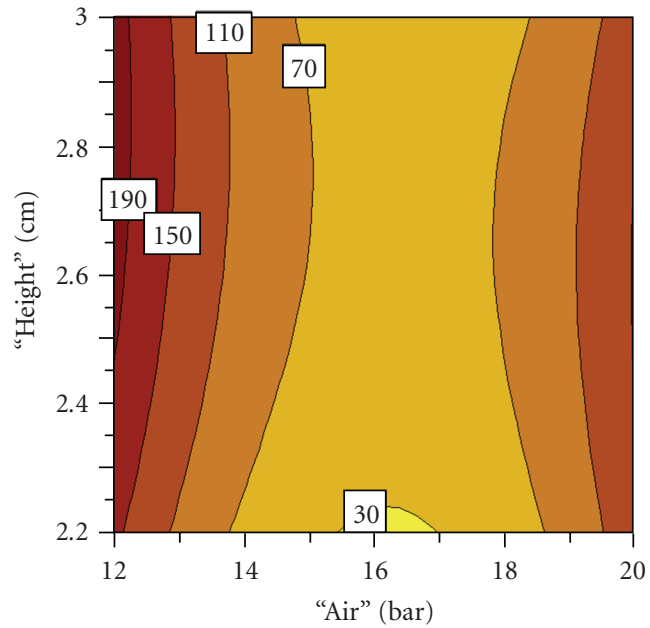

(d)

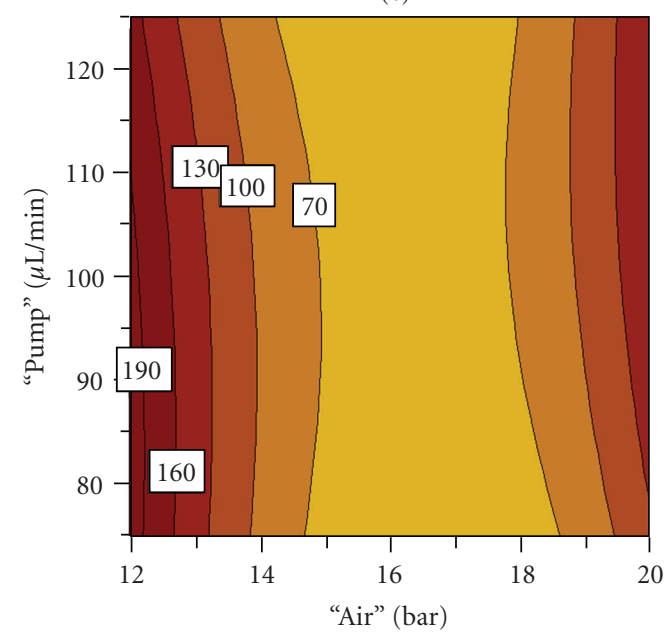

(e)

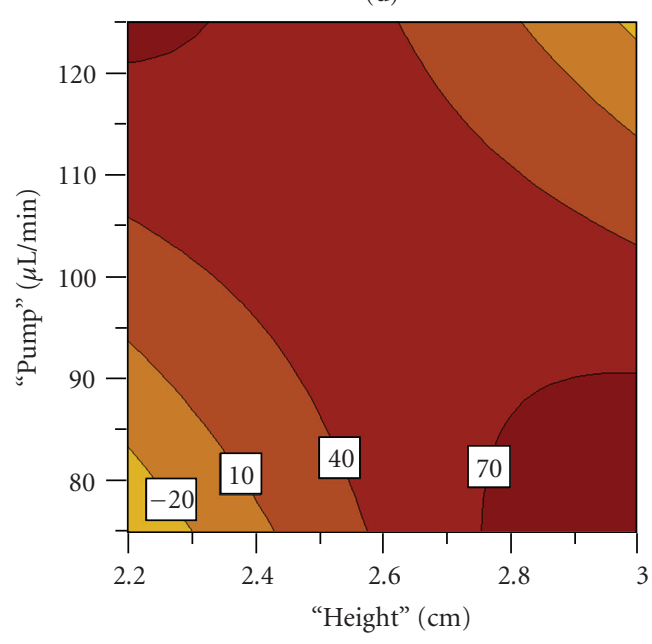

(f)

FIgURE 4: DoE analysis for the production of alginate microbeads containing IB3-1 cells. Contour plots of the responses: "size" (a)-(c) and "SD" (d)-(f). The following interactions were reported: "height versus air" (a,d); "pump versus air" (b,e); and "pump versus height" (c,f). 


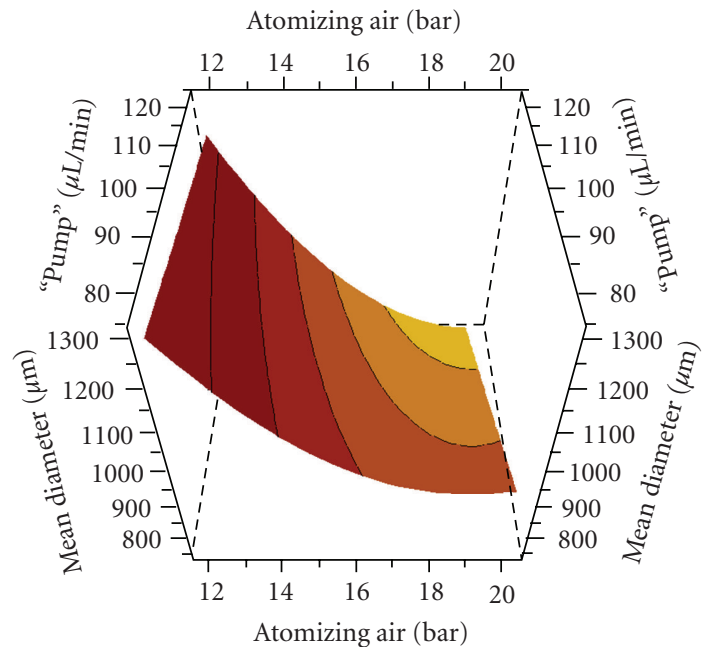

(a)

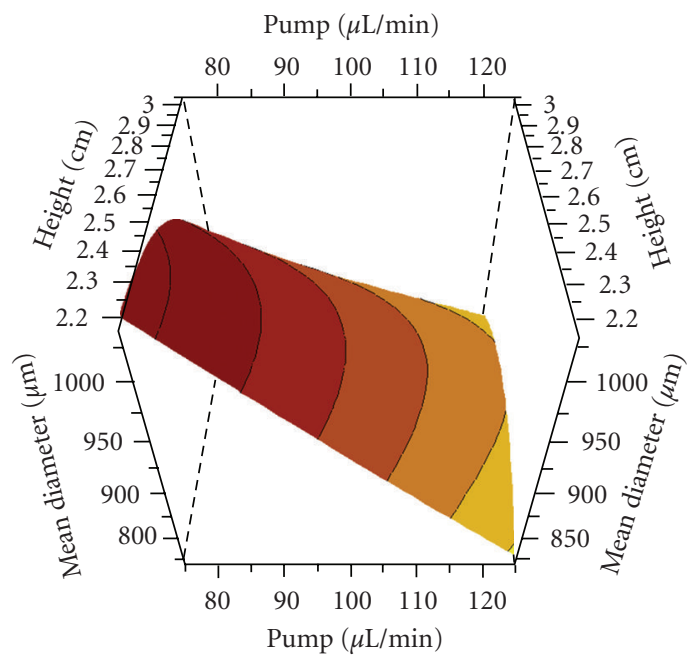

(c)

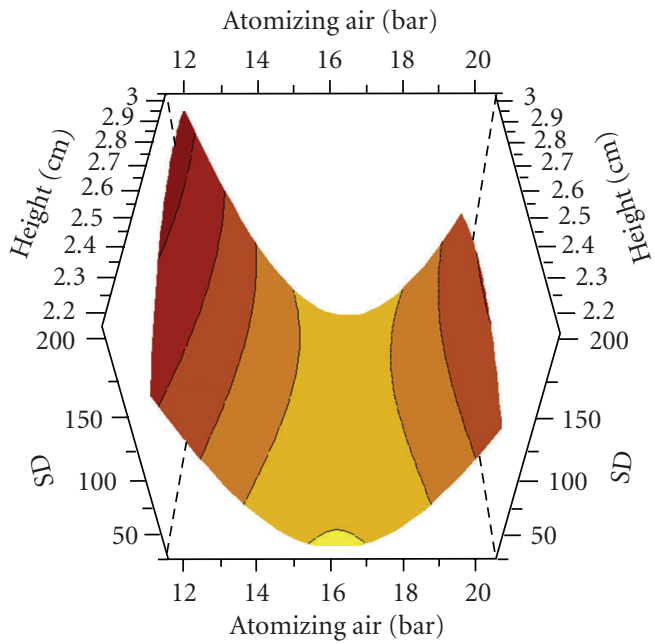

(e)

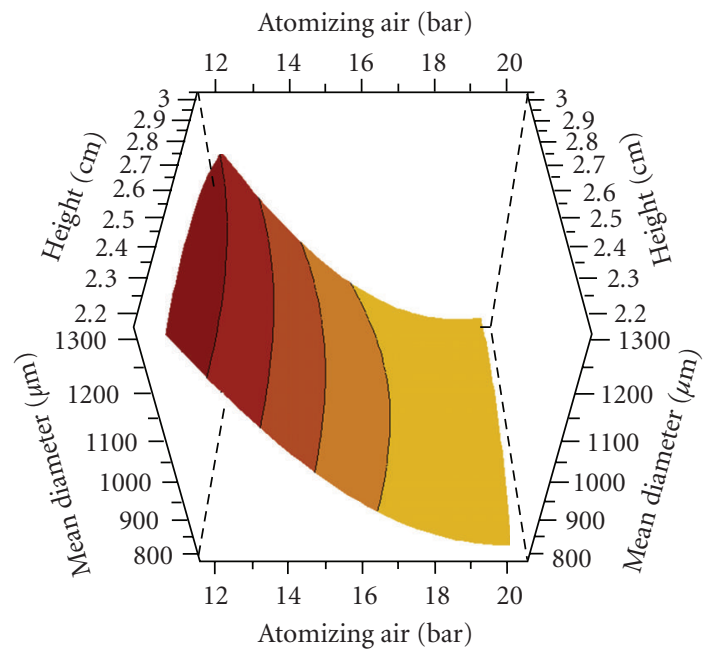

(b)

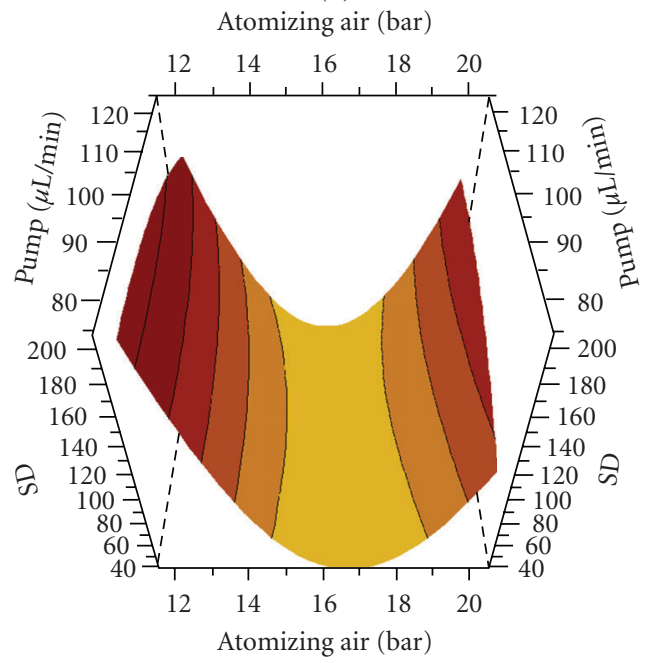

(d)

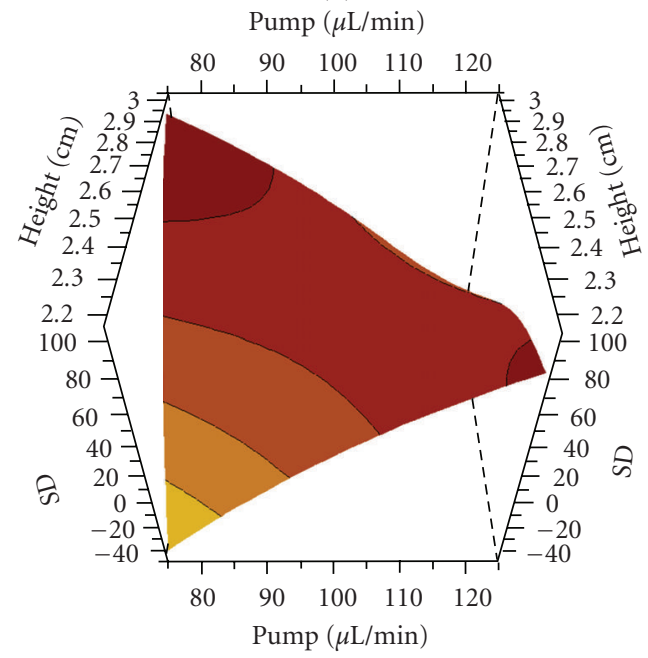

(f)

FIGURE 5: DoE analysis for the production of alginate microbeads containing IB3-1 cells. Response surface plots of the responses: "size" (a)-(c) and "SD" (d)-(f). The following interactions were reported: "air versus pump" (a,d); "air versus height" (b,e); and "pump versus height” (c,f). 


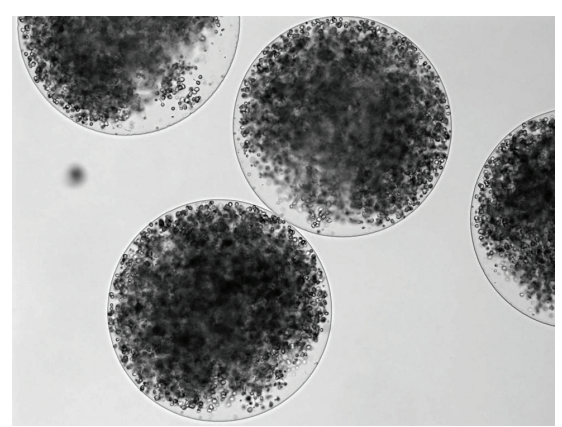

(a)

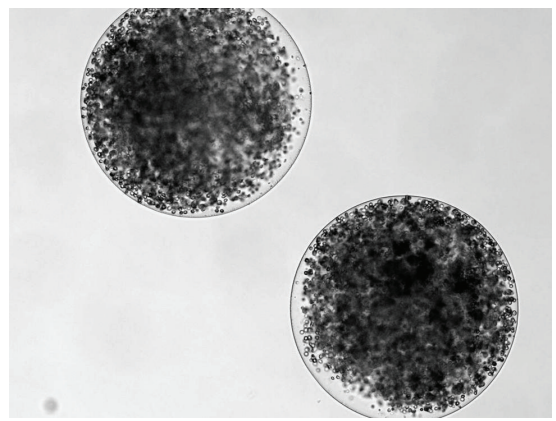

(c)

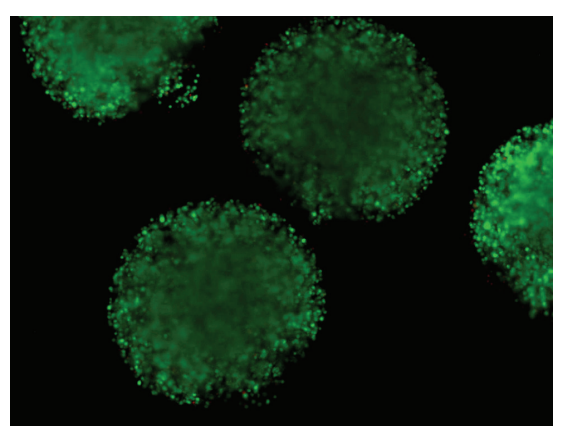

(b)

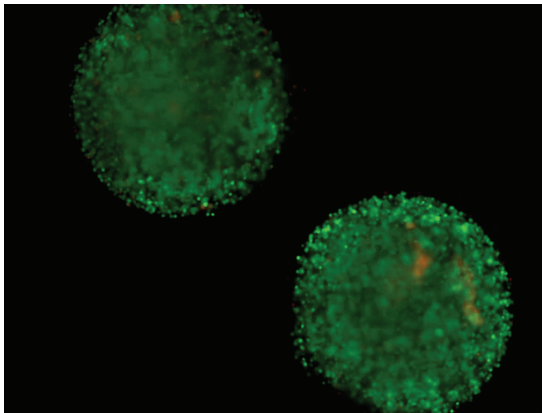

(d)

Figure 6: Optical $(\mathrm{a}, \mathrm{c})$ and fluorescence $(\mathrm{b}, \mathrm{d})$ photomicrographs of alginate microbeads containing IB3-1 cells after $1(\mathrm{a}, \mathrm{b})$ and 7 days $(\mathrm{c}, \mathrm{d})$ of cell culture. Fluorescence photomicrographs were taken after double staining with Calcein-AM and propidium bromide.

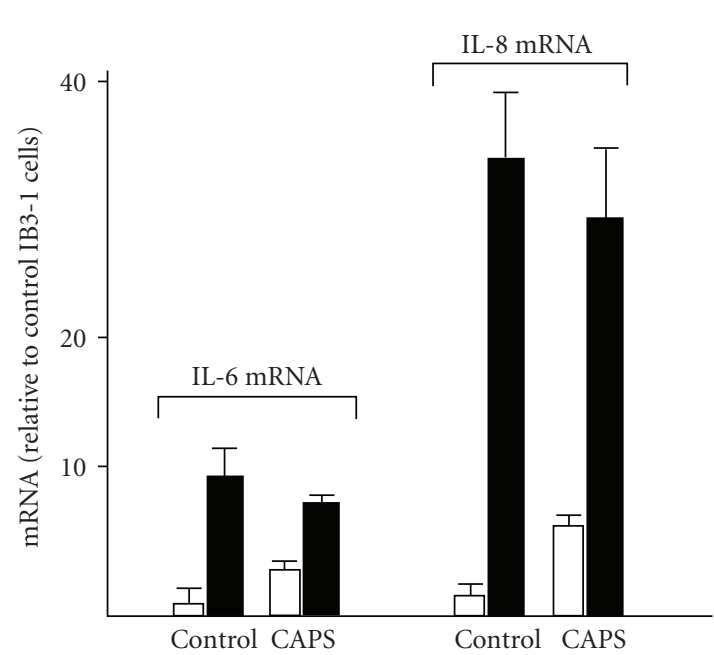

(a)

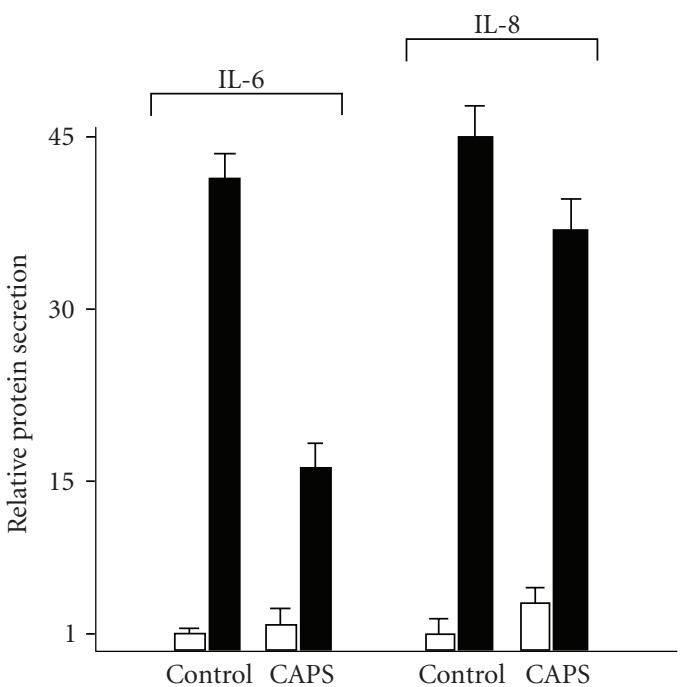

(b)

Figure 7: Analysis of the mRNA levels (a) and release (b) of interleukins 6 and 8 (IL-6, IL-8) by IB3-1 cells. Data are referred to control free cells growing as monolayer (control) and cells encapsulated in alginate microbeads (CAPS). Both free and encapsulated cells were cultured for 24 hours, in the absence (open bars) or in the presence of TNF- $\alpha(80 \mathrm{ng} / \mathrm{mL})$ (closed bars). Data represent the average \pm SD $(N=3)$.

In this respect, the use of cell-based drug delivery has been proposed as a very promising application of encapsulation of cells relevant for production of therapeutic proteins [29-33]. For instance, erythropoietin-secreting cells immobilized in microcapsules have been described by Murua et al. [29]. The applications in biomedicine of this strategy are very high, in consideration of the importance of erythropoietin for several biological functions, and the pathological conditions due to its disregulation. Similarly, continuous production of IL- 12 by microencapsulated engineered cells 
TABLE 1: Experimental design matrix and results of the DoE (design of experiments) approach for alginate microbeads.

\begin{tabular}{|c|c|c|c|c|c|}
\hline \multirow[b]{2}{*}{ Batch \# } & \multirow[b]{2}{*}{ Atomizing air (bar) } & \multicolumn{2}{|c|}{ Factors } & \multicolumn{2}{|c|}{ Responses } \\
\hline & & $\begin{array}{l}\text { Distance between the } \\
\text { nozzle and the gelling } \\
\text { bath }(\mathrm{cm})\end{array}$ & $\begin{array}{l}\text { Polymer pumping rate } \\
\quad \text { Pump }(\mu \mathrm{m} / \mathrm{mL})\end{array}$ & Mean diameter $(\mu \mathrm{m})$ & $\begin{array}{l}\text { Standard deviation } \\
\qquad( \pm \mu \mathrm{m})\end{array}$ \\
\hline & "air" & "height" & "pump" & "size" & "SD" \\
\hline$\# 1$ & 12.0 & 2.2 & 75.0 & 1350.5 & 63.2 \\
\hline$\# 2$ & 20.0 & 2.2 & 75.0 & 983.1 & 68.4 \\
\hline$\# 3$ & 12.0 & 3.0 & 75.0 & 1234.1 & 389.5 \\
\hline$\# 4$ & 20.0 & 3.0 & 75.0 & 917.5 & 60.5 \\
\hline$\# 5$ & 12.0 & 2.2 & 125.0 & 1177.5 & 296.5 \\
\hline$\# 6$ & 20.0 & 2.2 & 125.0 & 716.7 & 99.2 \\
\hline$\# 7$ & 12.0 & 3.0 & 125.0 & 1161.1 & 83.6 \\
\hline$\# 8$ & 20.0 & 3.0 & 125.0 & 724.8 & 106.7 \\
\hline$\# 9$ & 12.0 & 2.6 & 100.0 & 1293.6 & 47.6 \\
\hline$\# 10$ & 20.0 & 2.6 & 100.0 & 835.4 & 322.3 \\
\hline$\# 11$ & 16.0 & 2.2 & 100.0 & 970.5 & 54.8 \\
\hline$\# 12$ & 16.0 & 3.0 & 100.0 & 851.6 & 36.3 \\
\hline$\# 13$ & 16.0 & 2.6 & 75.0 & 920.6 & 47.2 \\
\hline$\# 14$ & 16.0 & 2.6 & 125.0 & 974.9 & 58.1 \\
\hline$\# 15 a$ & 16.0 & 2.6 & 100.0 & 920.8 & 43.1 \\
\hline$\# 15 b$ & 16.0 & 2.6 & 100.0 & 920.8 & 43.1 \\
\hline$\# 15 c$ & 16.0 & 2.6 & 100.0 & 920.8 & 43.1 \\
\hline
\end{tabular}

modified with murine interleukine-12 (mIL-12) gene has been reported by Zheng et al. [34]. The microencapsulated cells have a significant therapeutic effect on experimental colon tumors by activating antitumor immune responses in vivo. These and similar papers support the concept that microencapsulated and genetically engineered cells may be an extremely versatile tool for cellular therapy [35].

In our case, we demonstrate that microencapsulated cells can be induced to produce IL- 8 in the presence of high levels of TNF- $\alpha$. This result allows to hypothesize that the experimental strategy outlined allows the development of a "cell-based microparticle sensor" releasing specific proteins (selective release can be improved by changing the chemical composition of the microcapsules) [36] upon stimulation. This might be of great interest in biomedicine [35]. Bioencapsulation has been indeed shown to be efficacious in mimicking the cell's natural environment and thereby improves the efficiency of production of different metabolites and therapeutic agents, while protecting the cells from larger proteins (e.g., antibodies) and immune cells [29, 32, 35].

\section{Acknowledgments}

R. Gambari has received Grants from AIRC, Fondazione CARIPARO (Cassa di Risparmio di Padova e Rovigo), Cofin2002, Fondazione Fibrosi Cistica (FFC), UE ITHANET Project and Telethon (contract GGP07257). M. Borgatti has received a 2006 Young Investigator Grant from the University of Ferrara, Italy. This paper is also supported by
The Emilia-Romagna Region and by Associazione Veneta per la Lotta alla Talassemia, Rovigo. M. Borgatti and S. Mazzitelli contributed equally to this work.

\section{References}

[1] M. J. Welsh, L. C. Tsui, T. F. Boat, and A. L. Beaudet, "Cystic fibrosis," in The Metabolic and Molecular Bases of Inherited Disease, C. R. Scriver, A. L. Beaudet, W. S. Sly, and D. Valle, Eds., pp. 3799-3876, McGraw-Hill, New York, NY, USA, 1995.

[2] E. Puchelle, S. De Bentzmann, C. Hubeau, J. Jacquot, and D. Gaillard, "Mechanisms involved in cystic fibrosis airway inflammation," Pediatric Pulmonology, vol. 32, no. 23, pp. 143$145,2001$.

[3] D. M. Kube, D. Fletcher, and P. B. Davis, "Relation of exaggerated cytokine responses of CF airway epithelial cells to PAO1 adherence," Respiratory Research, vol. 6, article 69, 2005.

[4] A. M. Jones, L. Martin, R. J. Bright-Thomas et al., "Inflammatory markers in cystic fibrosis patients with transmissible Pseudomonas aeruginosa," European Respiratory Journal, vol. 22, no. 3, pp. 503-506, 2003.

[5] T. L. Bonfield, J. R. Panuska, M. W. Konstan et al., "Inflammatory cytokines in cystic fibrosis lungs," American Journal of Respiratory and Critical Care Medicine, vol. 152, no. 6, pp. 2111-2118, 1995.

[6] H. R. Black, J. R. Yankaskas, L. G. Johnson, and T. L. Noah, "Interleukin- 8 production by cystic fibrosis nasal epithelial cells after tumor necrosis factor- $\alpha$ and respiratory syncytial virus stimulation," American Journal of Respiratory Cell and Molecular Biology, vol. 19, no. 2, pp. 210-215, 1998. 
[7] S. W. J. Terheggen-Lagro, G. T. Rijkers, and C. K. van der Ent, "The role of airway epithelium and blood neutrophils in the inflammatory response in cystic fibrosis," Journal of Cystic Fibrosis, vol. 4, no. 2, pp. 15-23, 2005.

[8] T. Z. Khan, J. S. Wagener, T. Bost, J. Martinez, F. J. Accurso, and D. W. H. Riches, "Early pulmonary inflammation in infants with cystic fibrosis," American Journal of Respiratory and Critical Care Medicine, vol. 151, no. 4, pp. 1075-1082, 1995.

[9] T. Lund and B. Østerud, "The effect of TNF- $\alpha$, PMA, and LPS on plasma and cell-associated IL-8 in human leukocytes," Thrombosis Research, vol. 113, no. 1, pp. 75-83, 2004.

[10] V. Bezzerri, M. Borgatti, E. Nicolis et al., "Transcription factor oligodeoxynucleotides to NF- $\kappa$ B inhibit transcription of IL-8 in bronchial cells," American Journal of Respiratory Cell and Molecular Biology, vol. 39, no. 1, pp. 86-96, 2008.

[11] E. Boncoeur, V. S. Criq, E. Bonvin et al., "Oxidative stress induces extracellular signal-regulated kinase $1 / 2$ mitogenactivated protein kinase in cystic fibrosis lung epithelial cells: potential mechanism for excessive IL-8 expression," The International Journal of Biochemistry \& Cell Biology, vol. 40, no. 3, pp. 432-446, 2008.

[12] M. Borgatti, V. Bezzerri, I. Mancini et al., "Induction of IL-6 gene expression in a CF bronchial epithelial cell line by Pseudomonas aeruginosa is dependent on transcription factors belonging to the Sp1 superfamily," Biochemical and Biophysical Research Communications, vol. 357, no. 4, pp. 977983, 2007.

[13] E. DiMango, H. J. Zar, R. Bryan, and A. Prince, "Diverse Pseudomonas aeruginosa gene products stimulate respiratory epithelial cells to produce interleukin-8," The Journal of Clinical Investigation, vol. 96, no. 5, pp. 2204-2210, 1995.

[14] M. M. Chan, K. Chmura, and E. D. Chan, "Increased $\mathrm{NaCl}$-induced interleukin- 8 production by human bronchial epithelial cells is enhanced by the $\Delta \mathrm{F} 508 / \mathrm{W} 1282 \mathrm{X}$ mutation of the cystic fibrosis transmembrane conductance regulator gene," Cytokine, vol. 33, no. 6, pp. 309-316, 2006.

[15] P. de Vos, M. M. Faas, B. Strand, and R. Calafiore, "Alginatebased microcapsules for immunoisolation of pancreatic islets," Biomaterials, vol. 27, no. 32, pp. 5603-5617, 2006.

[16] A. Bertolotti, M. Borgogna, A. Facoetti, E. Marsich E, and R. Nano, "The effects of alginate encapsulation on NIT-1 insulinoma cells: viability, growth and insulin secretion," In Vivo, vol. 23, no. 6, pp. 929-935, 2009.

[17] G. Luca, M. Calvitti, C. Nastruzzi et al., "Encapsulation, in vitro characterization, and in vivo biocompatibility of sertoli cells in alginate-based microcapsules," Tissue Engineering, vol. 13, no. 3, pp. 641-648, 2007.

[18] O. Jubert, D. Keller, H. Monteil, L. Talbot, and G. Prevost, "Versatily of bio-plex system: application to the detection of bacterial protein toxins," Bio-Rad Bulletin, p. 3013, 2003.

[19] M. Borgatti, R. Rizzo, M. B. Dal Canto et al., "Release of sICAM-1 in oocytes and in vitro fertilized human embryos," PLoS ONE, vol. 3, no. 12, article e3970, 2008.

[20] R. Rizzo, M. B. Dal Canto, M. Stignani et al., "Production of sHLA-G molecules by in vitro matured cumulus-oocyte complex," International Journal of Molecular Medicine, vol. 24, no. 4, pp. 523-530, 2009.

[21] W. de Jager, H. Te Velthuis, B. J. Prakken, W. Kuis, and G. T. Rijkers, "Simultaneous detection of 15 human cytokines in a single sample of stimulated peripheral blood mononuclear cells," Clinical and Diagnostic Laboratory Immunology, vol. 10, no. 1, pp. 133-139, 2003.
[22] S. J. M. Skinner, M. S. Geaney, H. Lin et al., "Encapsulated living choroid plexus cells: potential long-term treatments for central nervous system disease and trauma," Journal of Neural Engineering, vol. 6, no. 6, Article ID 065001, 2009.

[23] M. Endres, N. Wenda, H. Woehlecke et al., "Microencapsulation and chondrogenic differentiation of human mesenchymal progenitor cells from subchondral bone marrow in Caalginate for cell injection," Acta Biomaterialia, vol. 6, no. 2, pp. 436-444, 2010.

[24] L. Penolazzi, E. Tavanti, R. Vecchiatini et al., "Encapsulation of mesenchymal stem cells from Wharton's jelly in alginate microbeads," Tissue Engineering Part C, vol. 16, no. 1, pp. 141$155,2010$.

[25] B. A. Woodworth, E. Tamashiro, G. Bhargave, N. A. Cohen, and J. N. Palmer, "An in vitro model of Pseudomonas aeruginosa biofilms on viable airway epithelial cell monolayers," American Journal of Rhinology, vol. 22, no. 3, pp. 235-238, 2008.

[26] Y. Altschuler, C. Hodson, and S. L. Milgram, "The apical compartment: trafficking pathways, regulators and scaffolding proteins," Current Opinion in Cell Biology, vol. 15, no. 4, pp. 423-429, 2003.

[27] C. A. Bertrand and R. A. Frizzell, "The role of regulated CFTR trafficking in epithelial secretion," American Journal of Physiology, vol. 285, no. 1, pp. C1-C18, 2003.

[28] S. Jaya, T. D. Durance, and R. Wang, "Effect of alginate-pectin composition on drug release characteristics of microcapsules," Journal of Microencapsulation, vol. 26, no. 2, pp. 143-153, 2009.

[29] A. Murua, G. Orive, R. M. Hernández, and J. L. Pedraz, "Xenogeneic transplantation of erythropoietin-secreting cells immobilized in microcapsules using transient immunosuppression," Journal of Controlled Release, vol. 137, no. 3, pp. 174-178, 2009.

[30] G. Orive, M. De Castro, H.-J. Kong et al., "Bioactive cellhydrogel microcapsules for cell-based drug delivery," Journal of Controlled Release, vol. 135, no. 3, pp. 203-210, 2009.

[31] A. Goren, N. Dahan, E. Goren, L. Baruch, and M. Machluf, "Encapsulated human mesenchymal stem cells: a unique hypoimmunogenic platform for long-term cellular therapy," The FASEB Journal, vol. 24, no. 1, pp. 22-31, 2010.

[32] B. E. Tuch, G. W. Keogh, L. J. Williams et al., "Safety and viability of microencapsulated human islets transplanted into diabetic humans," Diabetes Care, vol. 32, no. 10, pp. 18871889, 2009.

[33] Z. C. Liu and M. S. Chang, "Transdifferentiation of bioencapsulated bone marrow cells into hepatocyte-like cells in the $90 \%$ hepatectomized rat model," Liver Transplantation, vol. 12, no. 4, pp. 566-572, 2006.

[34] S. Zheng, Z.-X. Xiao, Y.-L. Pan, M.-Y. Han, and Q. Dong, "Continuous release of interleukin 12 from microencapsulated engineered cells for colon cancer therapy," World Journal of Gastroenterology, vol. 9, no. 5, pp. 951-955, 2003.

[35] P. de Vos, M. Bučko, P. Gemeiner et al., "Multiscale requirements for bioencapsulation in medicine and biotechnology," Biomaterials, vol. 30, no. 13, pp. 2559-2570, 2009.

[36] S. K. Tam, B. J. de Haan, M. M. Faas, J.-P. Hallé, L. Yahia, and P. de Vos, "Adsorption of human immunoglobulin to implantable alginate-poly-L-lysine microcapsules: effect of microcapsule composition," Journal of Biomedical Materials Research Part A, vol. 89, no. 3, pp. 609-615, 2009. 


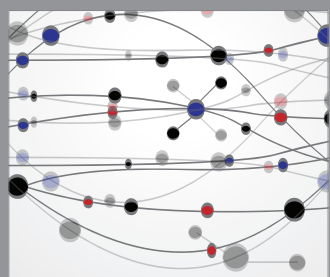

The Scientific World Journal
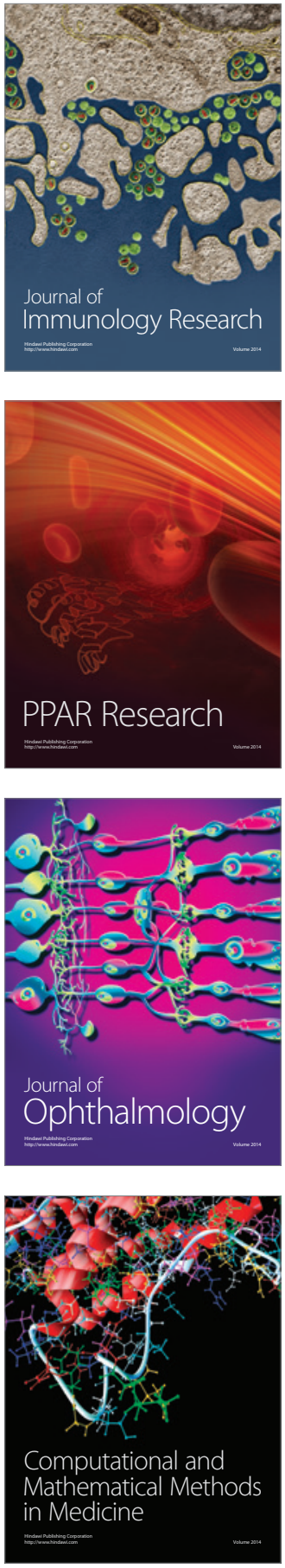

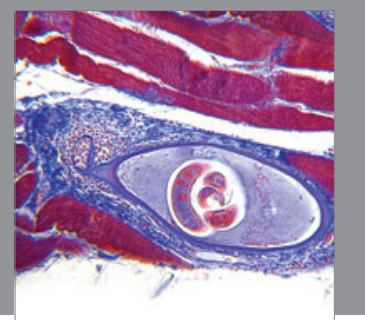

Gastroenterology

Research and Practice
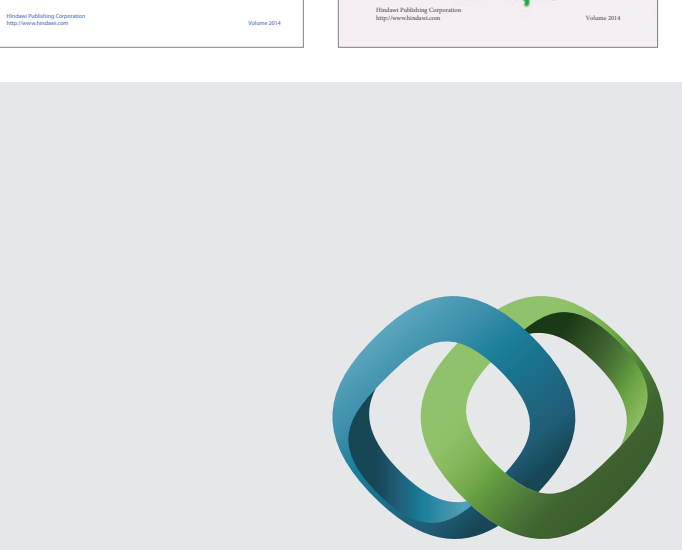

\section{Hindawi}

Submit your manuscripts at

http://www.hindawi.com
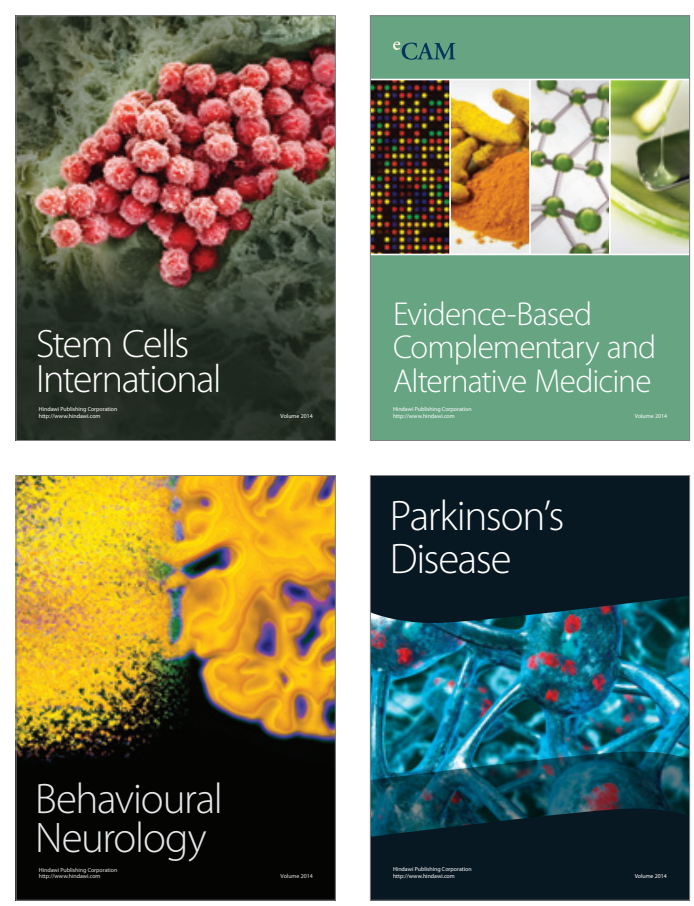

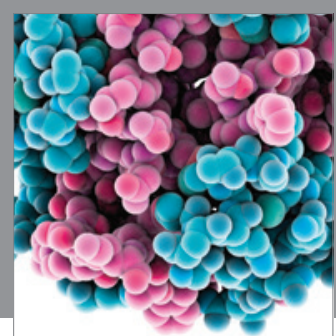

Journal of
Diabetes Research

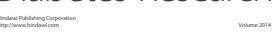

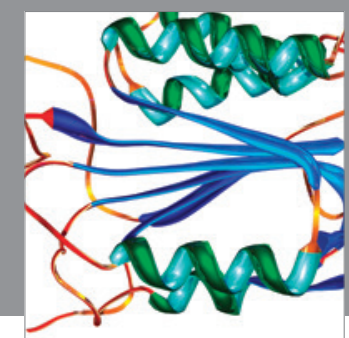

Disease Markers
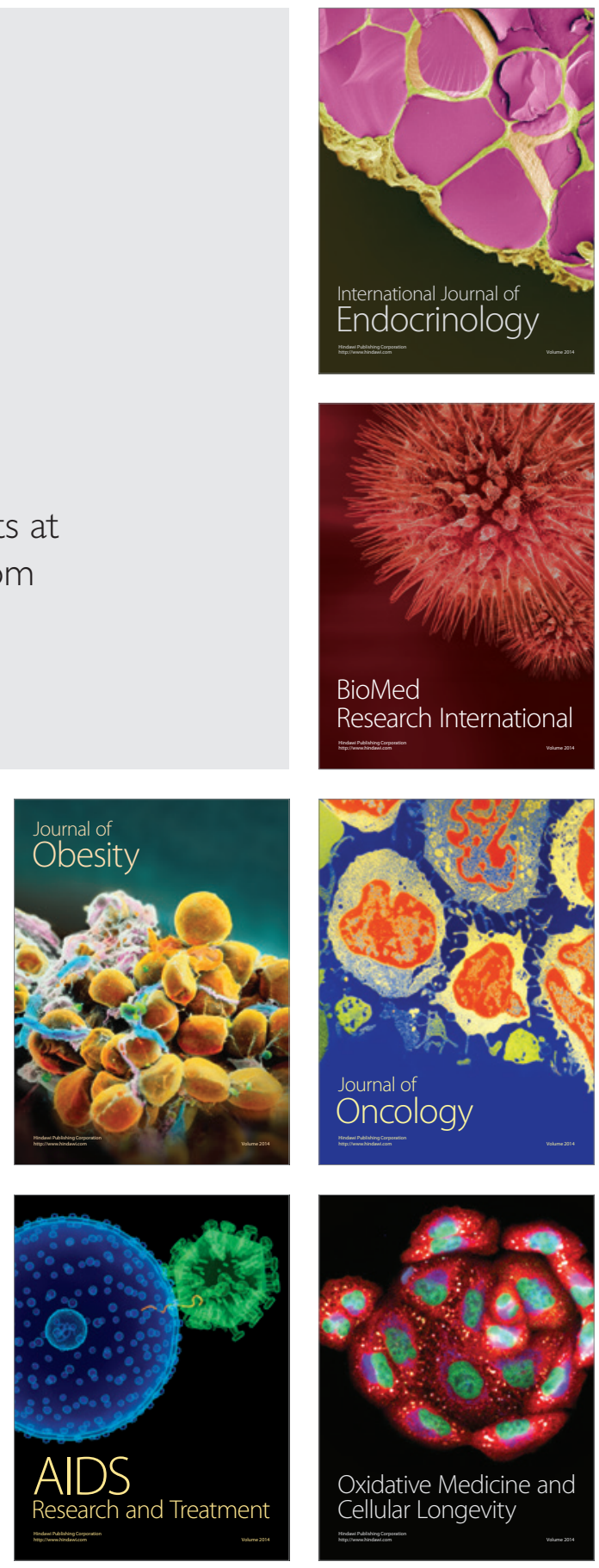